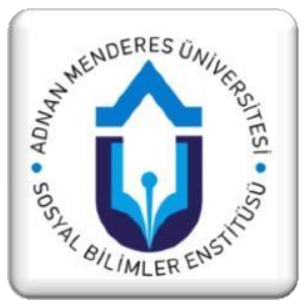

\title{
Toplumda Çevre Bilinci Olușturulabilir mi? Bir Grup Üniversite Öğrencisinin Görüşleri ${ }^{1}$
}

\author{
Hatice ÖNER ${ }^{2}$, Nermin KORUKLU 3
}

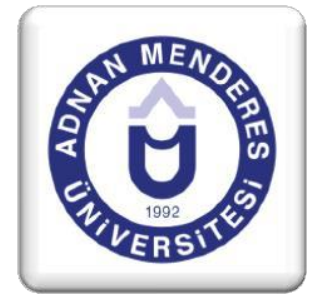

Özet

Araştırmada, Çevre Sağlı̆̆ı Ana Bilim Dalında lisans üstü eğitime devam eden öğrencilerin çevre bilincine yönelik görüşlerinin belirlenmesi amaçlanmıştır. Aydın Adnan Menderes Üniversitesi 2018-2019 eğitim öğretim yılı, Çevre Sağlığı Ana Bilim Dalı'nda lisans üstü eğitime devam eden 8 öğrenci araştırmanın çalışma grubunu oluşturmuştur. Çalışma grubu maksimum çeşitlilik örneklemesine göre belirlenmiştir. Çalışmada, nitel araştırma yöntemiyle durum çalışması deseni kullanılmıştır. Veriler, doküman analizi ile toplanmıştır. Verilerin değerlendirilmesinde tümevarımcı içerik analizi yöntemi kullanılmıştır.

Öğrencilere sorulan sorular temelinde; toplumda çevre bilincinin oluşmama nedenleri ve çevre bilincinin geliştirilmesine yönelik öneriler olmak üzere iki kategori ve bunlarla ilgili tema ve alt temalar belirlenmiştir. Öğrencilerin çevre bilincine yönelik görüşleri doğrultusunda bulgular yorumlanmıştır. Sonuç olarak, öğrenciler çevre bilincinin gelişmemesinde çok boyutlu faktörlerin etkili olduğunu, toplumun farkındalığının artırılmasında, uygulanabilir ve her yaş ve eğitim düzeyindeki bireyleri kapsayan ve arkasına medyanın ve devletin desteğini alan farklı eğitim modellerinin kullanılmasının önemli olduğunu vurgulamışlardır.

Anahtar Kelimeler: Çevre bilinci, Çevre sorunları, Çevre eğitimi

\section{Can an environmental awareness be raised in Society? Views of a Group of University Students}

\begin{abstract}
The object of this research is to determine the opinions of the students attending postgraduate education in the department of environmental health for an environmental awareness. The study group consisted of 8 students attending postgraduate education in the Department of Environmental Health at Aydin Adnan Menderes University during 2018-2019 academic years. The study group was determined according to the maximum variation sampling method. A case study design with a qualitative research method was used for this research. Data were collected by a document analysis. An inductive content analysis method was used for data evaluation. Based on the questions asked to the students, two categories, one being the reasons for not raising environmental awareness in society and the other being suggestions for improving environmental awareness, and the themes and sub-themes therefor were determined. The results were interpreted according to the students' opinions on environmental awareness. As a result, the students emphasized that multidimensional factors are effective for the environmental awareness not being developed and that it is important to use applicable different education models which include individuals of all ages and educational levels and get support from the media and government for increasing the environmental awareness.
\end{abstract}

Keywords: Environmental awareness, Environmental issues, Environmental education

\footnotetext{
${ }^{1} \mathrm{Bu}$ çalışma 2018-2019 eğitim öğretim döneminde yapılmıştır. Çalışmaya katılan gönüllülerden sözel onamlar alınmıştır. Araştırma 19-22 Haziran 2019, Ankara'da düzenlenen VI.th International Eurasian Educational Research Congress'de sözel bildiri olarak sunulmuştur

2 Aydın Adnan Menderes Üniversitesi Hemşirelik Fakültesi Ruh Sağlı̆̆ı ve Hastalıkları Hemşireliği Anabilim Dal1. Aydın. honer@adu.edu.tr.ORCID:0000-0002-6556-5753

${ }^{3}$ Aydın Adnan Menderes Üniversitesi Eğitim Fakültesi Eğitim Bilimleri Bölümü Rehberlik ve Psikolojik Anabilim Dalı. Aydın. nonerkoruklu@gmail.com ORCID:0000-0003-1577-8352
} 


\section{Giriş}

İnsanoğlunun çevreye egemen olma isteği ile birlikte çevrede çok yönlü değişimler görülmeye başlanmıştır (Hoşgör, Gündüz Hoşgör ve Tosun, 2015). Bu değişimler, çevrede yıkıcı ve geriye dönüşü olmayan bir takım sorunlara yol açmakta ve tüm canlıları olumsuz yönde etkilemektedir (Talas ve Karataş, 2012; Yurtcanlı Duymaz, 2013). Gelişen teknolojiye paralel olarak (Dolu ve Ürek, 2015; Çakırlar Altuntaş ve Turan, 2016), aşırı nüfus, sanayileşme ve kentleşmeye bağlı artan doğal kaynak tüketimi, ülkelerin gelişmişlik düzeyi ne olursa olsun dünyanın hemen her yerinde çevre sorununu öne çıkarmış ve tüm toplumları tehdit eder hale gelmiştir (Karabıçak ve Armağan, 2000; Karataş, 2013; Yazıcı ve Babalık, 2016). Çevre sorunlarının doğal sonucu olarak ekolojik dengede bozulmalarla birlikte insan ve diğer canlıların yaşamları risk altına girmiştir (Kaypak, 2013; Asilsoy ve Oktay, 2018). Çevre kirliliğine bağlı yaşanan sorunlar, sadece bulunduğu topluma değil, diğer tüm ülkeleri ve dolayısıyla toplumları da etkilemektedir (Karabıçak ve Armağan, 2004). Uzun dönemde ise gelecek kuşakları etkisi altına alacak ve hatta ekolojik dengeyi yok edecektir (Kaypak, 2013). Çevre sorunlarına bağlı geriye dönüşü olmayan sonuçların yaşanmaması için acilen ulusal ve uluslararası düzlemde, tüm insanlık olarak ele alınması gerekmektedir. $\mathrm{Bu}$ bağlamda, bir grup lisans üstü öğrencisinin, çevre sorunlarının yaşanmasında etkili olan nedenler ile çözüm yollarına ilişkin görüşlerinin ortaya konması, ilgili alan yazına katkı verecektir.

\section{2. Çevre Bilincinin Önemi}

Farkındalık ve bilinçlenme süreci değişim ve dönüşüm için temel olan iki kavramdır. Sorunların çözümü, dış yaptırımlar ve ceza sistemi ile değil her bir bireyin kendi davranışlarının sorumluluğunu alması ve devamında öz düzenlemeye gitmesi ile ancak mümkün olabilir (Çakırlar vd., 2016). Bireysel düzlemdeki bu adımlar beraberinde diğer bireyleri etkileyerek toplumsal boyutta bir farkındalığa ve bilinçlenmeye katkı sağlayabilir (Talas ve Karataş, 2012; Asilsoy ve Oktay, 2018). Hedeflenen çözüme, toplumu oluşturan her bir bireyin doğaya karşı duyarlılık göstermesiyle ulaşılabilir. Tüm toplumları etkileyen ve etkilemeye devam edecek olan bu yaşamsal sorunun önlenmesinde, çevre duyarlılı̆̆ 1 ve bilincin oluşturulması konusu çok önemli bir yere sahiptir. Çevre bilinci, bireyin çevresine ve topluma karşı sorumlu hissetmesi ile ilişkilidir (Şaşmaz Ören, Kıyıcı, Erdoğmuş ve Sevinç, 2010). Çevre bilinci, bir ülkenin sürdürülebilir kalkınmasının güçlendirilmesi (Yazıcı ve Babalık, 2016), çevreye yönelik tutumlarının niteliği ve olarak onun yaşama ilişkin genel değerleri ile yakından ilişkilidir (Asilsoy ve Oktay, 2018). Bireylerin yaşam değerleri, çevreye karş1 gösterilen genel tutum ve eylemlerin kapsam ve yönelimini etki edebilir (Olson ve Zanna,1994).

Çevre ile ilgili yaşanan sorunlarının evrenselliği, aynı zamanda bu sorunların çözümünde çok yönlü işbirliği ve eşgüdümü de gerekli kılmaktadır (Kaypak, 2013; Smirnova, 2018). Bu kapsamda, Birleşmiş Milletler Eğitim, Bilim ve Kültür Örgütü (UNESCO), Birleşmiş Milletler Çevre Programı (UNEP), Çevre Bakanlıkları, Üniversiteler, Belediyeler ve bazı Sivil Toplum kuruluşlarında çevreye yönelik çalışmalar yürütülmektedir (Şimşekli, 2004; Smirnova, 2018). Çevre ve çevredeki kirlenme sürecine yönelik son yıllarda uluslararası alanda yapılan faaliyetlerde, çevreyi koruma konusundaki ortak bilincin oluşmaya başlamasının önemli bir gelişme olduğu belirtilmektedir (Karabıçak ve Armağan, 2004). Bu süreçte, birey ve toplumları harekete geçirmede ve ortak bir bilincin oluşturulmasında başta eğitimciler olmak üzere farklı disiplinlerdeki profesyonellere çok büyük sorumluluklar düşmektedir (Şaşmaz Ören vd, 2010). 


\section{3. Çevre Eğitiminin Kapsamı}

Çevreye karşı pozitif tutum ve değer yargılarının oluşmasında çevre eğitimi bir zorunluluk olmakla birlikte (Çakırlar Altuntaş ve Turan, 2016; Oğuza, Çakıcı ve Kavasa, 2011) sürdürülebilir olması da gerekmektedir. Çevre eğitiminin amac1, toplumda çevre bilincini oluşturmada temel olan konuların ve kavramların, farklı disiplinlerle işbirliği içinde güncel eğitim yöntemleri kullanılarak, tutum ve davranışlarda değişim meydana getirmektir (Meiboudi, Karimzadegan ve Khalilnejad, 2011). Bu koşullar sağlandığı takdirde, insanın doğayla uyumlu yaşaması mümkün olabilecektir (K1lıç ve İnal, 2010; Talas ve Karataş, 2012; Asilsoy ve Oktay, 2018). Eğitimde özellikle, kaynakların ve çevrenin korunmasında, sürdürülebilir kalkınma hedefleri temelinde bireylerin ekolojik bilgileri artarken aynı zamanda bireylerin davranış örüntülerindeki değişimler ile toplumda pozitif tutum ortaya çıkabilir (Uzun, Sağlam ve Varnacı Uzun, 2008; Yazıcı ve Babalık, 2016). Bu kapsamda, araştırmacılar, hükümetler ve politika yapıcılar çevre bilinci ile bireylerin konuya yönelik duyarlılıklarını arttırmak amacıyla uygun çözümler ile bölgesel sorunlara ilişkin tutum değişikliğini teşvik etmeye çalışmaktadırlar (Asilsoy ve Oktay, 2018). Bu teşvikler ile istenen değişim ancak toplumun tüm kesimlerinin aktif katılımı ve sorumluluk alması ile mümkün olabilecektir. Yapılan çalışmalar değerlendirildiğinde, toplumlarda çevreye yönelik geliştirilmesi gereken en önemli unsurun çevre ya da doğa sevgisi olduğu görülmektedir. $\mathrm{Bu}$ sevginin bireylerde oluşturulması için eğitimde farklı yöntemler ön plana çıkmaktadır. Çevre eğitiminde son yıllarda, "teknik çözüm", "doğa sevgisi", ve "toplumsal uyanış" olmak üzere üç kavramın önemi vurgulanmaya başlamıştır (Özdemir, 2007). Çevreye karşı bu değerlerin öğretilmesinde eğitim önemli bir araç olarak (Çetin ve Nisanci, 2010) toplumsal bilinci, duyarlılığ 1 ve eleştirel düşünceyi geliştirerek sosyal yaşama olan uyumu kolaylaştırır (Tokat ve Mutlu, 2004). Çevre eğitiminin etkinliğinin artmasında, tüm yaklaşımları kapsayan bütüncül bir bakış açısının benimsenmesi gerekmektedir (Özdemir, 2007). Bu kapsamda, çevre eğitiminde temel hedef, doğaya değer veren, dayanışma ruhunu yaşatan bireylerin, toplumsal süreçlere katılımını destekleyici ve farkındalığı geliştirici nitelikte olması gerekmektedir (Özdemir, 2007; Karataş, 2013). Birey ve toplumlarda, çevreye yönelik değerlerin oluşturulması ve sürdürülmesinde eğitim ile birlikte temel kanunlar ve yasal düzenlemelerin eş güdümlü olarak yürütülmesi gereklidir.

Bilinç ve farkındalık kazanımına okul öncesi dönemden başlanılması gerekmektedir (Çukur ve Özgüner, 2008). Çocukluk döneminde doğa bilinci eğitim ile kazandırılabilecekken (Çukur ve Özgüner, 2008) bu yaş döneminde yer alan öğretim programlarında istenilen değeri görmemiştir Ancak çevre ve çevre konusu ile ilgili farklı dersler, eğitim öğretim müfredatında önemli bir ders olarak görülmemiştir (Tokat ve Mutlu, 2004). Yaygınlığının artırılmasının yanı sıra, çocukların çevreyi benimsemeleri ve ona karşı değer oluşturmaları için farklı eğitim yöntemlerinin kullanılması gereklidir (Şimşekli, 2004). Konuyla ilgili yapılan bir çalışmada, çevre konusu ile ilgili yapılan araştırmaların daha çok ortaokul düzeyinde kaldığı vurgulanmıştır (Çakırlar Altuntaş ve Turan, 2016). Oysa çevre ve çevrenin korunması sadece bir yaş ya da eğitim seviyesindeki kişilere özgü değil, tüm insanlığı ilgilendiren sürekli gündemde olması gereken bir konudur. Tüm eğitim basamaklarında olduğu gibi, üniversiteler arasında da çevre bilincinin oluşturulmasına yönelik yenilikçi programlara ihtiyaç vardır (Karataş, 2013). Buna karşın, üniversite öğrencilerinin çevresel farkındalığının beklendiği düzeyde olmadığı vurgulanmaktadır (Yazıcı ve Babalık, 2016).

Çocukluk süreci ile birlikte geniş toplumsal katılımın esas alındığı politikalar ile çevre konusunda toplumun kararlara katılımlarının artırılması gerekmektedir (Karataş, 2013; Yurtcanlı Duymaz, 2013). Bu kapsamda politika yapıcıların, akademisyenlerin, endüstri 
uzmanlarının, bütün toplumu oluşturan bireylerin, Dünya'nın doğal kaynaklarını korunmasında çok yönlü sorumlulukları vardır (Karataş, 2013; Yurtcanlı Duymaz, 2013). Birey ile çevre arasındaki bozulan dengenin sağlanabilmesi için herkesin bu sürece gönül vermesi, aktif olarak katkı sağlaması gerekir.

Bireylerde çevrenin korunmasına yönelik bilinç gelişmesinde, medyanın rolü yadsınamaz bir gerçektir (Erdoğan ve Uşak, 2009; Anılan, 2014; Sola, 2014) Medya sayesinde, çevre için atılan adımların yaygınlaşması hız kazanabilir. Literatürde çevre bilinci üzerine yapılan araştırmaların daha çok nicel desende tanımlayıcı tipte kaldığı görülmüştür. Oysa çevre bilincinin geliştirilmesine yönelik daha farklı yöntem ve çalışma gruplarında yapılacak araştırmalar ile konu çok yönlü olarak ele alınabilir. Bununla birlikte, özellikle alanda uzmanlık eğitimi alan bir grup lisansüstü öğrencisinin çevre bilincinin geliştirilmesine yönelik görüşlerinin ortaya konması, literatüre farklı bir açıdan katkı verecektir.

\section{Yöntem}

$\mathrm{Bu}$ bölümde araştırmanın amacı, araştırma soruları, araştırma deseni, çalışma grubu ve kullanılan veri toplama aracı hakkında açıklayıcı bilgiler verilmiştir.

\subsection{Araştırmanın Amacı ve Soruları}

$\mathrm{Bu}$ araştırmada, çevre sağlığ 1 alanında lisansüstü eğitime devam eden bir grup öğrencinin toplumda çevre bilincinin oluşturulmasına yönelik görüşlerinin ortaya konması amaçlanmıştır.

$\mathrm{Bu}$ genel amaç doğrultusunda aşağıdaki sorulara yanıt aranmıştır.

1.Çevre sağllğ lisansüstü eğitimine devam eden öğrencilerin, toplumda çevre bilincinin oluşturulmasına yönelik görüşleri nelerdir?

2.Çevre sağllğı lisansüstü eğitimine devam eden öğrencilerin, toplumda çevre bilincinin oluşturulmasına yönelik önerileri nelerdir?

\subsection{Araştırma Deseni}

$\mathrm{Bu}$ araştırmada, nitel araştırma yöntemlerinden tek durum çalışma deseni kullanılmıştır. Durum çalışmasında amaç belirli bir duruma ilişkin sonuçları ortaya koymaktır. Bir araştırma yöntemi olarak kabul edilen durum çalışmasının literatürde örnek olay incelemesi ya da vaka çalışması gibi farklı isimleri mevcuttur (Subaşı ve Okumuş, 2017). Durum çalışması olaylar ve davranışlar hakkında zengin ve önemli bakış açıları sağlamasından dolayı önemli bir bilgi edinme yöntemidir. Ayrıca, gerçek yaşam olaylarının bütünsel ve anlamlı özelliklerini ortaya çıkarmaya yardımcı olmaktadır. Bu araştırmada, "toplumda çevre bilincinin oluşması" ile ilgili görüşler çalışılan durum olarak belirlenmiştir. Nitel durum çalışmasının en önemli özelliği bir ya da birkaç durumun derinliğine araştırılmasıdır (Aytaçl1, 2012; Yıldırım ve Şimşek; 2016). Araştırmaya katılan çevre sağlığı yüksek lisans ögrencilerinin, çevre sağlığı alanındaki aldıkları eğitimler ve deneyimleri temelinde hareket edilerek, araştırmayı durum çalışması modelinde kurgulamanın daha uygun olacağı düşünülmüştür. Araştırmada, çalışma grubunun o duruma ilişkin algıları ve görüşlerini ortaya koymak amaçlanmıştır.

\section{3.Çalışma Grubu}

Çalışma, Aydın Adnan Menderes Üniversitesi Sağlık Bilimleri Enstitüsü Çevre Sağlığı Anabilim Dalı Lisansüstü programına devam eden 8 öğrenci ile Nisan 2019 tarihinde yapılmıştır. Çalışma grubu, amaçlı örnekleme tekniklerinden biri olan maksimum çeşitlilik örnekleme tekniğinden yararlanılarak oluşturulmuştur. Maksimum çeşitliliğe dayalı örneklem oluşturmada amaç, çeşitlilik gösteren durumlar arasında herhangi ortak ya da 
paylaşılan olguların olup olmadığını bulmaya çalışmak ve bu çeşitliliğe göre problemin farklı boyutlarını ortaya koymaktır (Yıldırım ve Şimşek, 2016). Bu nedenle araştırmanın çalışma grubu oluşturulurken cinsiyet, yaş, mezun olunan okul, meslek, çalışma durumları dikkate alınmıştır.

Araştırmaya katılan öğrencilere ait kişisel bilgiler aşağıda verilmiştir.

Tablo 1. Araştırmaya Katılan Öğrencilere Ait Kişisel Bilgiler

\begin{tabular}{|c|c|c|c|c|c|}
\hline $\begin{array}{l}\overline{0} \\
\overline{0} \\
: 0 \\
: 0\end{array}$ & 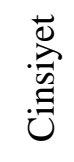 & $\stackrel{\pi}{\varpi}$ & 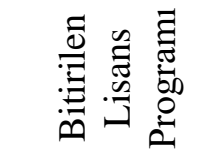 & 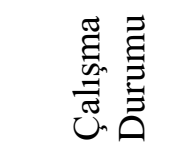 & 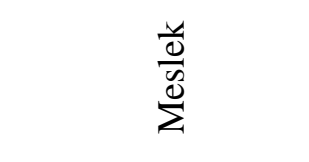 \\
\hline Ö1 & $\mathrm{K}$ & 27 & $\begin{array}{c}\text { Sağl1k } \\
\text { Yönetimi }\end{array}$ & Çalışıyor & Öğretim görevlisi \\
\hline Ö2 & $\mathrm{K}$ & 33 & Matematik & Çalışıyor & Matematik uzmanı \\
\hline Ö3 & $\mathrm{E}$ & 27 & $\begin{array}{l}\text { Konaklama } \\
\text { İşletmeciliği }\end{array}$ & Çalışmıyor & Turizm \\
\hline Ö4 & $\mathrm{K}$ & 26 & $\begin{array}{c}\text { Acil Yardim } \\
\text { ve Afet } \\
\text { Yönetimi }\end{array}$ & Çalışıyor & Acil tıp teknisyeni \\
\hline Ö5 & $\mathrm{E}$ & 35 & İşletme & Çalışmıyor & Öğretim görevlisi \\
\hline Ö6 & $\mathrm{K}$ & 23 & $\begin{array}{c}\text { Sosyal } \\
\text { Hizmet }\end{array}$ & Çalışmıyor & $\begin{array}{c}\text { Sosyal hizmet } \\
\text { uzman }\end{array}$ \\
\hline Ö7 & $\mathrm{K}$ & 28 & Hemşirelik & Çalışıyor & Hemşire \\
\hline Ö8 & $\mathrm{E}$ & 36 & İşletme & Çalışıyor & Memur \\
\hline
\end{tabular}

Çalışmaya katılan öğrencilerin \%62.5'u (5) kadın, \%37.5'u (3) erkek, öğrencilerin yaş ortalaması $X=29$ olarak bulunmuştur. Aynı şekilde öğrencilerin \%62.5'nin (5) çalıştığı, \%37.5'nun (3) çalışmadığı ortaya çıkmıştır. Öğrencilerin yüksek lisans eğitimine devam etme nedenlerine bakıldığında, özel bir alanda ilerleme isteği, çevreye karşı duyarlı olması, akademisyen olma hedefi, bu alanda doktora eğitimine devam etme isteği, lisans sırasında halk sağlığı dersinden verim alması, vatana millete hayırlı evlat olmak, bilgisini ve tecrübelerini yeni nesle aktarabilmek, Batman Hasankeyf ilçesinin sular altında kalmaması için yoğun bir çalışma yapması, yaşadığımız var olduğumuz çevreyi daha iyi tanıyabilme isteği şeklinde ifade ettikleri görülmüştür.

\subsection{Veri Toplama Aracı}

Nitel araştırmalarda veri toplama araçlarından biri de doküman (narrative) analizidir (Yıldırım ve Şimşek, 2016). Veri toplama aracı olarak öğrenciler hakkında genel bilgiler toplamayı sağlayan 8 adet soru ile ilgili alan yazın taranarak oluşturulan ve toplumda çevre bilincinin oluşmama nedenleri nelerdir? ve çevre bilincinin geliştirilmesine yönelik önerileriniz nedir? olmak üzere iki adet açık uçlu sorudan oluşan soru formu kullanılmıştır. 


\subsection{Geçerlik ve Güvenirlik}

Nitel araştırmalarda geçerlik kullanılan veri toplama aracının, gerçekleştirilen işlemlerin ve verilerin uygunluğunu ifade ederken; güvenirlik çalışmanın tutarlılığı hakkında bilgi verir (Creswell, 2015). Araştırmada, geçerliğin sağlanmasında inandırıcılık ve aktarılabilirlik, güvenirliğin sağlanmasında tutarlılık stratejilerine başvurulmuştur. Katılımcıların görüşlerine odaklanan çalışmalarda inandırıcılığı arttırmak amacıyla katılımcıların onayına başvurulabilir. Yazılı dokümanlar araştırmacılar tarafından yazılı hale dönüştürülmüş ve bu metin ilgili kişilere tekrar gönderilerek kontrol etmeleri istenmiş, böylece katılımcı teyidi alınmıştır (Creswell, 2015).

Araştırmanın dış geçerliğini (aktarılabilirliğini) artırmak için araştırma süreci ve bu süreçte yapılanlar ayrıntılı bir şekilde açıklanmaya çalışılmıştır. Bu bağlamda, araştırmanın deseni, çalışma grubu, veri toplama aracı, veri toplama süreci, verilerin çözümlenmesi ve yorumlanması ayrıntılı bir biçimde tanımlanmıştır.

Araştırmanın iç güvenirliğini (tutarlığını) artırmak için bulguların tamamı yorum yapılmadan doğrudan verilmiştir. Nitel araştırma konusunda deneyimli bir öğretim üyesi tarafindan araştırma deseni, yarı yapılandırılmış görüşme soruları ve verilerin kodlanması sürecinde geri bildirim alınmıştır. Ayrıca veriler üzerinde ayrı ayrı kodlamalar yapmış ve kodlamalar karşılaştırılarak ortak kararla kategori, tema ve alt temalar belirlenmiştir.

Araştırmanın dış güvenirliğini (teyit edilebilirliğini) artırmak için araştırmacı, süreçte yapılanları ayrıntılı bir biçimde tanımlamıştır. Ayrıca elde edilen ham veriler ve kodlamalar başkaları tarafından incelenebilecek şekilde araştırmacı tarafindan saklanmaktadır.

\subsection{Verilerin Analizi}

Araştırma kapsamında verilerin analizinde, nitel veri analiz tekniklerinden tüme varımcı içerik analizi yöntemi kullanılmıştır (Yıldırım ve Şimşek, 2016).Veriler toplandıktan sonra verilerin ham dökümü bilgisayara araştırmacılar tarafından yazılmıştır. İçerik analizinde temelde yapılan işlem, birbirine benzeyen verileri belirli kavramlar ve temalar çerçevesinde bir araya getirmek ve bunları okuyucunun anlayabileceği bir biçimde düzenleyerek yorumlamaktır. Analiz için veriler anlamlarına göre bölünerek kodlanmıştır (açık kodlama), belirli bir anlam etrafinda birbiri ile ilgili kodlar bir araya getirilecek (dikey kodlama) ve dikey kodlamada belirlenen çekirdek kategoriler birleştirilerek temalar oluşturulmuştur (seçici kodlama) ve yorumlanarak anlamlı hale getirilmiştir. Bulguların yorumlanmasında olası yönlendirmeleri engellemek amacıyla herhangi bir kategoriye yerleştirilemeyen, ayrılık gösteren veriler de göz önünde bulundurulmuştur.

\subsection{Etik}

Araştırmanın yürütülebilmesi için gerekli izinler alınmıştır. Ayrıca araştırmanın amacı, araştırmanın eğitim sürecine ve çevre sağlığı alanına olacak katkısı açıklandıktan sonra öğrencilerin her birinden sözel onam alınmıştır.

\section{Bulgular}

Çalışma grubuna sorulan sorulardan elde edilen bulgular tablo 2'de verilmiştir 
Tablo 2. Öğrencilerin Çevre Bilincine Yönelik Görüşleri

\begin{tabular}{|c|c|c|}
\hline Kategori & Tema & Alt Tema \\
\hline $\begin{array}{l}\text { Toplumda Çevre } \\
\text { Bilincinin Olusmama }\end{array}$ & 1.Toplumun Farkındalığ1 & $\begin{array}{l}\text { 1.Zararın boyutundan } \\
\text { farkında olmama }\end{array}$ \\
\hline \multirow{10}{*}{ Nedenleri } & & 2. Kültür fark1 \\
\hline & & 3. Eğitim fark1 \\
\hline & & 4. "Bana ne" düşüncesi \\
\hline & 2 Prooramların Niteliŏ & $\begin{array}{l}\text { 1.Çalışmaların insanlara } \\
\text { yeterince dokunamaması }\end{array}$ \\
\hline & 2. 10 б & $\begin{array}{l}\text { 2.Ülke gündeminde çok az } \\
\text { yer alması }\end{array}$ \\
\hline & 3.Eğiticinin Niteliği & $\begin{array}{l}\text { 1.Halkın anlayacağı dilden } \\
\text { konuşulmaması, } \\
\text { 2. Öğretmenlerin konu ile } \\
\text { ilgili bilinçsizliği }\end{array}$ \\
\hline & & $\begin{array}{l}\text { 1.Okullarda çevre eğitiminin } \\
\text { teorik düzeyde kalması }\end{array}$ \\
\hline & 4.Egitimin Nitelig1 & $\begin{array}{l}\text { 2.Eğitim yöntemiyle ilgili } \\
\text { hatalar }\end{array}$ \\
\hline & & $\begin{array}{l}\text { 3.Çevre } \\
\text { yetersizliği }\end{array}$ \\
\hline & 5.Yönetsel & $\begin{array}{l}\text { 1.Denetleme } \\
\text { mekanizmasının yeterli } \\
\text { olmaması. }\end{array}$ \\
\hline \multirow{4}{*}{$\begin{array}{l}\text { Çevre Bilincinin } \\
\text { Geliş̧irilmesine } \\
\text { Yönelik Öneriler }\end{array}$} & 1.Eğitim & 1.Eğitimcilerin eğitilmesi \\
\hline & & $\begin{array}{l}\text { 2.Eğitim faaliyetlerinin } \\
\text { topluma inmesi }\end{array}$ \\
\hline & & $\begin{array}{l}\text { 3.Okul öncesi eğitim-öğretim } \\
\text { programlarında, çevre } \\
\text { eğitimi }\end{array}$ \\
\hline & & üniversitenin \\
\hline
\end{tabular}




\author{
bölümlerinde çevre eğitimi \\ dersinin olmasi \\ 5.Bilimsel araştırmaların \\ kullanımı \\ 6.Eğitim yöntemlerinin \\ geliştirilmesi
}

2.Birey /aile sorumluğu

1.Çevre sevgisi ailede başlar

3.Toplum Kat1lımı

1.Çocukların çevresel etkinliklerde yer almaları

2.Çevre ile ilgili yapılan çalışmalara halkın katılımının sağlanması

3.Hastanelerde çevre bilincini artırma çalışmaları

4.Medyanın Kullanımı
1.Sosyal medyanın aktif kullanılması

2.Kamu spotlarının etkinleştirilmesi

Öğrencilere sorulan iki açık uçlu soru temelinde toplumda çevre bilincinin oluşmama nedenleri ve çevre bilincinin geliştirilmesine yönelik öneriler olmak üzere iki kategori ve bunlarla ilgili tema ve alt temalar belirlenmiştir. Toplumda çevre bilincinin oluşmama nedenleri kategorisi kapsamında, "toplumun farkındalığı", "programların niteliği”, "eğiticinin niteliği”, "eğitimin niteliğì" ve "yönetsel” olmak üzere beş tema saptanmıştır. Çevre bilincinin geliştirilmesine yönelik öneriler kategorisi temelinde "eğitim", "birey /aile sorumluğu", "toplum katılımı", "medyanın kullanımı" olmak üzere dört tema ortaya çıkmıştır. Aşağıda her bir kategori ve temalar kapsamında öğrenci ifadeleri yer almaktadır.

\section{Kategori 1:Toplumda çevre bilincinin oluşmama nedenleri}

Bu kategori temelinde, "toplumun farkındalığı", "programların niteliği”, "eğiticinin niteliği”, "eğitimin niteliği" ve "yönetsel" olmak üzere beş tema ve alt temalar ortaya çıkmıştır.

“Toplumun Farkındalığı” teması ile ilgili öğrenci görüşleri incelendiğinde, zararın boyutundan farkında olmama, kültür farkı, eğitim farkı, "bana ne" düşüncesi, insanların çevreyi tükenmeyecek, sonu olmayan bir kaynak olarak görmeleri şeklinde alt temalar ortaya çıkmıştır. Toplumun farkındalığının oluşmamasında, birey, aile ve toplumsal boyutta, 
ekonomik ve kültürel faktörlerin engel oluşturduğu belirtilmiştir. Bu tema ve alt temalarla ilgili olarak 2 nolu öğrenci, "insanlar çevreye verdikleri zararın ciddiyeti ve boyutunun farkında olmayabilir veya bilmiyor olabilir" diyerek düşüncesini açıklamıştır. Yine 1 nolu öğrenci "Çevre sorunlarını sadece çarpık kentleşme ve hava kirliliği gibi kısıtlı konularla sinırlı zannediyorlar. Sera etkisinden, küresel ısınmadan, biyolojik bozulmalardan hiç bahseden yok" ifadesi ile toplumun çevre sorunları hakkında yeterli bilgi birikiminin olmadığını, güncel durumdan haberdar olmadıklarını ifade etmeye çalışmıştır. Eğitim ve kültür farkına vurgu yapan 3 nolu öğrenci, "toplumda eğitim ve kültür farkının çevre bilincinin oluşmamasında etkili olduğunu düşünüyorum” demiştir. Çocuğun yaşadığı ortamda uygun rol modellerin olmamasının gelecekte "bana ne" düşüncesine sahip bireylere zemin hazırlayacağına ilişkin olarak 4 nolu öğrenci, "bilinç kavramının okul öncesi dönemde başladığını kabul ettiğimizde, rol model alınan ebeveyn ve toplumdaki bireyler -bana nebilinciyle devam ettiği sürece, çocuklukta kalıcı öğrenme sağlayamıyoruz ve bilinci oturtamıyoruz" demiştir. Ekonomik kaygılar nedeniyle farkındalık oluşmadığını vurgulayan 5 nolu öğrenci, "toplumun bakış açısı genellikle günü kurtarma üzerine kurulu. Gelecek nesillerin durumundan ziyade ekonomi öncelikli konu" diye düşüncesini ifade etmiştir.

"Programların niteliği”" teması ile ilgili olarak saptanan alt temalar, çalışmaların insanlara yeterince dokunamaması ve ülke gündeminde çok az yer alması olarak belirlenmiştir. Burada öğrenciler çevre ile ilgili düzenlenen programların bireylerde davranış olarak herhangi bir değişim oluşturamadığını belirtmiş̧lerdir. Bununla ilgili olarak, 1 nolu öğrenci, "çevre bilincini oluşturmak için yapılan çalışmaların bireylere yeterince dokunamaması, etkili olmaması olabilir" diyerek düşüncesini açıklamıştır. Yine eğitim programlarının uygulama temelli olmamasında bir engel oluşturduğunu savunan 6 nolu öğrenci, "bilgiye dayalı sistemler ve sorunlar üzerine konuşmak yerine alanda uygulamada bulunmak önem arz ediyor. Uygulamalarda yetersiz kalmış bir ülkeyiz” diyerek fikrini dile getirmiştir. Etkin bir program ancak ülke gündeminde medya aracılığ ile daha geniş topluluklarla temas edebilir. Bu kapsamda 8 nolu öğrenci, "çevre gibi önemli bir konunun ülke gündeminde, sosyal medyada ve TV'de çok az yer almasının” önemli bir sorun olduğunu düşündüğünü belirtmiştir.

"Eğitimin ve eğiticinin niteliği”" temalarına ilişkin öğrenci görüşlerine bakıldığında; halkın anlayacağı dilden konuşulmaması ve öğretmenlerin konu ile ilgili bilinçsizliği, okullarda çevre eğitiminin teorik düzeyde yapılması, eğitim yöntemiyle ilgili hatalar, çevre eğitiminin yetersizliği alt temaları belirlenmiştir. Öğrenciler, okul müfredatında çevre ile ilgili derslerin alanda pek bilgisi olmayan eğiticimler tarafından ve daha klasik bir eğitim yöntemi ile verilmesinin öğrencide bir etki oluşturmayacağı vurgulamışlardır. Bununla ilgili olarak, 2 nolu öğrenci, "bence bunun nedeni, daha ilköğretimde başladı̆̆ öne sürülen çevre eğitiminin yeterli olmaması, sını öğretmenleri ve fen bilgisi öğretmenleri konu hakkında çok bilinçsiz" demiştir. Çevre konusunun eğitimin her aşamasında üzerinde durulması gereken bir konu iken gerekli önemin verilmediği belirtilmiştir. Konuyla ilgili olarak, 8 nolu öğrenci, "çevre derslerinin seçmeli olması, ilköğretim ve lisede uygulamanın çok az olması" diyerek, 1 nolu öğrenci, "okullarda çevre eğitiminin teorik düzeyde yapılması olabilir" ifadeleri ile eğitim ve eğiticinin niteliği ile ilgili aşılması gereken sorunları dile getirmişlerdir.

"Yönetsel" temasına ilişkin görüşlerden denetleme mekanizmasının yeterli olmaması ve halkın bilinçli olarak cahil bırakılması alt temaları saptanmıştır. Bir öğrenci, çevre 
konusunda devleti yönetenlere büyük sorumluluk düştüğünü vurgulamıştır. Tema ile ilgili olarak, 4 nolu öğrenci, "devlet politikalarının baştan savma kağıt üzerinde kalması, denetleme mekanizmasının yeterli olmaması" olarak görüşünü ifade etmiştir.

\section{Kategori 2: Çevre bilincinin geliştirilmesine yönelik öneriler}

$\mathrm{Bu}$ kategori ile ilgili olarak "birey /aile sorumluğu", "toplum katılımı", "medyanın kullanımı" olmak üzere dört tema ve alt temalar belirlenmiştir.

"Eğitim" teması kapsamında, eğitimcilerin eğitilmesi, eğitim faaliyetlerinin sahaya inmesi, okul öncesi eğitim-öğretim programlarında çevre eğitimi, ödül-ceza uygulamaları, tüm üniversitenin bölümlerine yayılması ve bilimsel araştırmaların kullanımı alt temaları ortaya çıkmıştır. Öğrenciler genel olarak, okul öncesinden başlamak üzere yükseköğretimi de kapsayan ve öğrencilerin gelişimsel özelliklerine uygun farklı eğitim yöntemlerinin kullanılmasının önemini vurgulamışlardır. Yine eğitimin etkinliğini artırıcı yöntemlerin de işe koşulması gerektiği vurgulanmıştır. Okul öncesi dönemin önemini vurgulayan 3 nolu öğrenci, "çevre bilincinin gelişmesi için öncelikle okul öncesi eğitim-öğretim programlarında çevre eğitiminin başlanması gerektiğini düşünüyorum. Çünkü insanlar alışkanlıklarına küçük yaşta başllyor ve hayat boyu devam ediyor" şeklinde görüşünü ifade etmiştir. Eğitsel faaliyetlerin klasik bir eğitim yöntemi yerine eğlenceli olması gerektiğini savunan 6 nolu öğrenci, "öğretici aktivitelerin uygulanmasina ve bu süreçte toplumun her kesiminin katkısının sağlanmasına önem verilmelidir. Bu aktiviteleri eğlenceli bir şekilde yapmak önemlidir" şeklinde düşüncesini açılamıştır. Üniversitelere de büyük sorumluluk düştüğünü vurgulayan 8 nolu öğrenci, "eğitim fakültelerinde uygulamalı ve bilinçli ögrenciler yetiştirme ve bunu tüm üniversitenin bölümlerine yayılması ile bu sayede duyarlı bir toplum yetiştirilebilir" şeklinde fikrini açıklamıştır. Eğitimin özellikle aktif öğretim yöntemlerinden yaparak yaşayarak öğrenme modeli temelinde yürütülmesi gereği dile getirilmiştir. Bununla ilgili olarak 1 nolu öğrenci, "öğrenciler doğa ile iç içe olmalı. Ekolojik dengeyi görerek, dokunarak, hissederek öğrenmeli. Bir böceğin, arının, havanın önemini iliklerinde hissetmeli, ağaçların oksijen ürettiğini bilmeleri dışında ă̆açları tanımalı. Çocuklar böylece hayvanların, havanın, ağaçların da çok değerli varlıklar olduğunu farkına varır" ifadesi ile eğitimde dokunsal ve duygusal temasın önemini vurgulamıştır.

"Birey /aile sorumluğu" teması ile ilgili öğrenci görüşlerinden, çevre sevgisi aile ile başlar ve kararların yaşama geçirilmesi alt temaları belirlenmiştir. Özellikle ailenin bu noktada çok önemli olduğunu, çocuğa çevreye karşı duyarlı1ığı öğretmede ailelerin rol model olması gerektiği vurgulanmıştır. Bu tema ile ilgili olarak 6 nolu öğrenci, "öncelikle ailede başlaması gerektiğini düşünüyorum. Çocuk yetiştirecek ailelere çocuklarının çevreye duyarlı nasıl yetiştirileceği üzerine eğitim vermek şart” şeklinde görüşünü dile getirmiştir.

“Toplum katılımı” teması bağlamında, çocukların çevresel etkinliklerde yer almaları, çevre ile ilgili yapılan çalışmaların halka daha fazla duyurulması, farkındalığın artırılması, hastanelerle işbirliği ile çevre bilinci artırma, etkinliklerin eğlenceli olmasının sağlanması olmak üzere beş alt tema ortaya çıkmıştır. Toplum katılımı olmadan çevre bilincine ilişkin olarak istendik nitelikte bir değişim ve farklılaşma olamayacağı ifade edilmiştir. Bununla bağlantılı olarak, 1 nolu öğrenci, "çevrenin korunması gerektiğini herkes biliyor, ama kaç kişi eylemleri ile hayata geçiriyor? Öncelikle bu bilgiyi düşünceyi eyleme dökme aşamasında 
çalışmalar yapılmalı. Insanlar harekete geçirilmeli" ifadesi ile toplumun motive edilmesi gerektiğini belirtmiştir. Yine 5 nolu öğrenci, "çevre bilinci her yaş grubunda ayn geliş̧imi sağlamak zor olduğundan genç yaştakilere çevre bilincini aşılamak daha etkin uygulanabilir" cümlesiyle gençlik döneminin bu konuda daha etkin ve yararlı olabileceğini vurgulamıştır. Toplumda farklı kurumlarında, süreçte etkin olması gerektiğine ilişkin olarak 5 nolu öğrenci, "hastanelerle işbirliğine gidilip çevre bilinci artırllarak daha etkin mücadele gerçekleştirilebilir" şeklinde düşüncesini açıklamıştır. Çevreye yönelik bilincin gelişimi, bireyden başlamak üzere toplumun geneline yayılacağı belirtilmiştir. Çocukluk döneminin kritik bir dönem olduğunu vurgulayan 3 nolu öğrenci, "çocuklarda küçük yaşta çevre eğitimi başlanmalı, çevre bilinci aşılanmal, çevresel etkinliklerde yer almaları sağlanmalıdır" demiştir. Toplum katılımının artırılmasında, nitelikli politikaların desteğine gereksinim olduğu vurgulanmıştır.

"Medyanın Kullanımı" teması ile ilgili olarak; sosyal medyanın aktif kullanılması, kamu spotlarının etkinleştirilmesi olmak üzere iki alt tema ortaya çıkmıştır. Bu bağlamda 4 nolu öğrenci, "ăgaç dikmek erozyonu önler cümlesi, çevreye de uyarlanabilir. Halkın algısını farkındalığın artırmamı gerekli. Kamu spotu yapılabilir" diyerek etkin reklamın önemini vurgulamıştır. Yine 1 nolu öğrenci, "yakın zamanda poşet kullanımının ücretli olması insanlarda bilinç oluşumunda katkı sağladı. Ancak bence kamu spotları ile bu uygulamanın gerekçesi, nedeni daha belirgin halka anlatılmalyydı" demiştir. Sosyal medyanın aktif kullanılması gerekliliğini vurgulayan 1 nolu öğrenci, "video izleme sitelerinde çıkan reklamlara billboardlara $v$ b. yerleştirilerek farkındalık oluşturulabilir" şeklinde görüşünü dile getirmiştir. Medyanın özellikle çevre bilincinin oluşturulmasındaki önemi ve farkındalığın artırılmasındaki katkısına vurgu yapılmıştır.

\section{Sonuç ve Tartışma}

Çevre sağlı̆ğ alanında lisans üstü eğitime devam eden bir grup öğrencinin, toplumda çevre bilincinin geliştirilmesine yönelik görüşlerinin ortaya konması amacıyla yapılan çalışmada, nitel araştırma yöntemi kullanılmıştır. Araştırma sonucunda; çevre konusunda toplumun bilinç düzeyinin düşük olduğu, çevre eğitiminde gerek eğitici gerek eğitim yöntemi bağlamından çok önemli sorunlar yaşandığı, çevre eğitiminin okul öncesi dönemden başlamak üzere tüm eğitim kademelerini kapsaması gerektiği, çevre bilici, oluşabilmesi için devlet ve toplumun tüm boyutlarının eş güdümlü hareket etmesi gerektiği ve bu süreçte medyanın çok önemli rolü olduğu ifade edilmiştir.

Araştırma bulgularından, "toplumda çevre bilincinin oluşmama nedenleri" ve "çevre bilincinin geliştirilmesine yönelik öneriler" kategorileri ve bunlarla ilişkili saptanan tema ve alt temalar ilgili literatür bağlamında aşağıda tartışılmıştır.

Toplumda çevre bilincinin oluşmama nedenleri kategorisi ile ilişkili "toplumun farkındalığı", "programların niteliğıi", "eğiticinin niteliği", "eğitimin niteliği” ve "yönetsel" olmak üzere beş tema belirlenmiştir. Çevre, sağlıklı bir toplumun varlığının devamlılığında ve güven temelli insan ilişkilerinin kurulmasında çok önemli bir değerdir (Çetin ve Nişancı, 2010). Çevre ile ilgili yaşanan tüm sorunların en temel nedeni, insanın değer yargıları ve yaşam biçimleridir (Karaca, 2007). Bu noktada insanlar çevreyi kendi hizmetinde bir araç olarak görmekte ve doğanın bütünlügünü kavrayamamaktadırlar (Talas ve Karataş, 2012). Oysa değerler, tutumlardan veya inançlardan farklıdır. Bu araştırmada öğrenciler, çevre bilincinin gelişmemesinde çok boyutlu faktörlerin etkili olduğunu, bilinçsizlik olarak tanımlanan durumun sadece halkta değil aynı zamanda eğiticilerde de söz konusu olduğunu 
belirtmişlerdir. Çevre eğitimi ile ilgili ilköğretimde verilen derslerin hem nicelik hem de nitelik anlamında yetersiz kaldığı, çevre eğitimi derslerinin teorik olarak işlendiğini ancak uygulamalı olarak yürütülmesi gerektiğini ifade etmişlerdir. Literatürde konuyla ilgili bir çalışma sonucu araştırmamızdaki öğrencilerin ifadelerini destekler niteliktedir. Çalışma da, okulların çevre eğitimi duyarlılığının istenilen düzeyde olmadığı inceleme, deney türü etkinliklere daha az yer verildiği, ilköğretimde çevre konusunun acil çözülmesi gereken bir sorun olarak algılanmadığı ortaya konmuştur (Şimşekli, 2004). Bir başka çalışmada ise, öğretmenlerin büyük bir çoğunluğu, seçmeli olarak verilen "çevre ve insan" dersinin orta öğretim kurumlarının çoğunda açılmadığını, olanlarda ise, öğrencilere çevre eğitimi ile ilgili bilgi ve becerilerin kazandırılamadığını ve bunun öğrencilerde "çevre ve insan" dersine ilişkin ilgiyi de yok ettiğini ifade etmişlerdir (Uzun ve Sağlam, 2007). Çevre eğitiminin ve eğiticinin niteliği ile ilgili temalarda öğrenciler, eğitimin yetersizliği, eğitim yöntemindeki hatalar ve öğretmenlerin konu ile ilgili bilinçsizliğine vurgu yapmışlardır. Özellikle, öğretmenin çevreye karşı duyarlı ve olumlu duygular içinde olması, çocukların olumlu bilimsel ve çevresel gelişimini de destekleyebilir (Littledyke, 2008). Eğitimde, duyguların çok önemli rolü vardır. Konuyla ilgili yapılan bir başka çalışmada, eğitim fakültesi öğrencilerinin çevreye yönelik tutumlarının hemşirelik, inşaat ve çevre mühendisliği bölümlerine göre anlamlı düzeyde düşük olduğu saptanmıştır (Bodur ve Şenyuva, 2013). Öğretmenlik gibi çok kutsal bir mesleği temsil edecek ve yeni nesillerin yetişmesinde çok önemli sorumluluğunu alacak öğrencilerin, çevre konusundaki tutumlarının diğer bölümlere göre düşük olması oldukça düşündürücüdür. Eğitimin niteliğinin önemini vurgulayan bir araştırmada, elektromanyetik kirlilik konusunda fen bilimleri alanında lisansüstü eğitim gören öğrencilerin, sosyal bilimde okuyanlara göre daha farkında oldukları ancak lisans üstü düzeye gelmiş pek çok öğrencinin de elektromanyetik kirlilikle ilgili olarak hiçbir bilgisi olmadığı, bu kavramları hiç duymadıkları ifade edilmiştir (Dolu ve Ürek, 2015). Bu sonuçlar, araştırmamızda öğrencilerin ifade ettiği programların bireylere yeterince dokunamaması ve eğitim ile eğiticinin nitelikleri temalarıyla ilişkilendirilebilir. Üniversitede çevre konusunda ders ya da farklı eğitim programlarının yeterli olmaması aynı zamanda bireylerin katılımını ve içselleştirmeyi hedefleyen nitelikli programlara ihtiyacın olduğunu da göstermektedir. Bununla bağlantılı olarak yapılan bir çalışmada, yüksekokul öğrencilerinin, çevre hakkında bilgi edinmek için ders kitaplarının dışına çıkmadıkları, farklı kitaplardan okumalar yapmadıkları ortaya çıkmıştır (Anılan, 2014). Bu bulguyu destekleyen bir başka çalışmada öğretmenler, okulda çevre konularıyla ilgili uygulama olanaklarının olmadığını, kuramsal ve pratik bilgilerin yeterince verilemediğini, doğal ortam çalışmalarına olanak sağlanmadığı ve gündemde olan çevre sorunlarına yeterince değinilmediği için öğrencilerin çevreye karşı duyarlı bireyler olarak yetiştirilemediğini ifade etmişlerdir (Uzun ve Sağlam, 2007). Formal eğitim sürecinde öğrencide çevreye karşı olumlu duygu ve tutumların oluşturulması, eğitim ortamının her bakımdan (yöntem, teknik ve nitelikli eğitim ortamı vb.) geliştirilmesi gereğini ortaya koymaktadır. Benzer bir şekilde Hoşgör ve arkadaşlarının (2015) yaptıkları çalışma sonucunda da lisans eğitimine devam eden bir grup öğrencinin çevre duyarlılıklarının düşük çıktığı belirtilerek, bu sorunun çözümü kapsamında ögretim programına çevre ile ilgili derslerin ve dersi yürütecek öğretim elemanlarının eğitilmesinin gerektiği vurgulanmıştır.

Çevre bilincinin oluşmama nedenlerinden birisi de yönetsel olarak tanımlanmıştır. Öğrenciler, özellikle çevre politikalarının belirlenmesi ve denetleme mekanizmalarının işletilmesi konusunda yöneticilerin yetersiz kaldığını ifade etmişlerdir. Bu bulguyu destekleyen bir çalışmada Türkiye'de kirliliğin önlenmesine yönelik hizmetlerin dünya ülkelerine göre yetersiz kaldığı belirtilmiş ve politikaların bu kapsamda yeniden düzenlenmesinin önemi vurgulanmıştır (Sezen, 2017). Araştırma kapsamında öğrenciler 
çevre bilincinin oluşturulmasında devlet ve halkın bir bütün ve eşgüdümlü olarak hareket etmesi gerektiğini belirtmişlerdir. Bununla bağlantılı olarak yapılan bir çalışmada, yüksekokul öğrencilerinin, devletin çevre kirliliğini kontrol altına almak için aldığı karar ve düzenlemeler hakkında, yeterli bilgiye sahip olmadıkları ortaya çıkmıştır (Anılan, 2014). Bu anlamda, devletin çevre konusunda çok yönlü olarak varlığını göstermesinin önemli olduğu düşünülmektedir. Çevre eğitiminin başarılı olması, eğitimin yaygınlaştırılması, temel eğitim süresinin artırılması, çevre derslerinin artırılması ve yaygınlaştırılması gibi siyasal kararlar için devlete önemli sorumluluklar düşmektedir (Kılıç ve İnal, 2010). Bu bağlamda, devlet tarafindan geleneksel vatandaşlık yerine, çevre yasalarının ve mevzuatın güncellenmesine ve ekolojik vatandaşlığın bir ilke olarak toplumsal yapı içinde yerleştirilmesine gereksinim vardır (Asilsoy ve Oktay, 2018).

Çevre bilincinin geliş̧irilmesine yönelik öneriler kategorisi kapsamında "eğitim", "birey/aile sorumluluğu", "toplum katılımı" ve "medyanın kullanımı" temaları belirlenmiștir. Bulgular değerlendirildiğinde, öğrencilerin çevre bilincinin geliştirilmesinde çok yönlü çözümler önerdikleri, konunun sadece belli bir grubun sorunu değil her kesimden kişi ve kurumların ilgilenmesi gereken bir konu olarak değerlendirdikleri anlaşılmaktadır.

Eğitim, bireylerde istendik nitelikte davranışların ortaya çıkması ya da var olan tutumların değişmesi için gerekli bir süreçtir. Çevre eğitimi ailede başlamakla birlikte, okul öncesi dönem ve devamındaki diğer eğitsel aşamalar ile tüm toplumu kapsayacak şekilde yaşam boyu devam etmesi gereken önemli bir süreçtir (Çetin ve Nişanc1, 2010). Eğitimin sürekliliği ve sürdürülebilirliğinin yanı sıra, bireylerde farkındalık sağlama gibi önemli kazanımlar sağladığına ilişkin çalışmalar vardır (Aminrad, Zakariya, Hadi ve Sakari, 2013; Şimşekli, 2015). Bununla ilgili olarak yapılan bir çalışmada, aktif öğrenme ile birlikte yeşil sınıf modeli uygulamasının, öğrencilerin çevre bilinci düzeylerini artırdığı ifade edilmiştir (Çetin ve Nişanc1, 2010; Uzun, Sağlam ve Varnacı Uzun, 2008). Farklı eğitim modelleri ve yöntemlerinin kullanıldığı çevre eğitimlerinin, ailelerin, öğretmenlerin farkındalık ve bilgi birikimlerini artırdığı ve devamında çocukların çevreye yönelik olumlu tutumlarının oluşmasına yardım ettiği vurgulanmaktadır (Aminrad vd., 2013). Yine mobil telefonun kullanımının hızla arttığı günümüz toplumunda, iletişim aracı olan telefonun aynı zamanda öğrencilerin çevre konusunda farkındalığının artırılmasında da yararlı olduğu bulunmuştur (Uzunboylu vd., 2009). Çevre eğitimi, bireylerin çevreye karşı sorumlu davranışlarını geliştirmeye yönelik ve doğaya karşı duyulan sevgi ve saygıyı benimseten bir anlayış içinde verilmesiyle ancak amacına ulaşacaktır (Littledyke, 2008).

Kuşkusuz eğitim, toplumun geneline kapsayan nitelikte olmalıdır. Toplumun bir bölümüne verilecek eğitimin, çevre sorunlarının önlenmesinde kalıcı bir değişim yaratmada yeterli olamayacağ 1 düşünülmektedir. Çevre bilincinin geliştirilmesinde tüm toplumun katılımı gereklidir. İşletmelerde çalışan personelin çevre bilincinin geliştirilmesi amacıyla yapılan çalışma sonucunda çevre bilincinin oluşması için sadece bir eğitim programının yetmeyeceği, bireylerin kültürü, değerleri ile uyumlu ve gereksinimler temelinde oluşturulmuş sürdürülebilir programların daha etkin olacağı belirtilmiştir (Perron, Cote ve Duffy, 2006). Bunun gibi toplumda çevreye karşı duyarlılığın artırılmasında toplum liderleri, sivil toplum kuruluşları önemli sorumluluklar üstlenerek süreçte kolaylaştırıcı unsur olabilirler (Sola, 2014). Eğitim programlarının kültüre özgü ve farklı disiplin ve kuruluşlar tarafından desteklenmesinin önemi büyüktür. Ayrıca, daha geniş bir bakış açısı ile değerlendirildiğinde, verilen eğitim programların tutum ve davranışlarda değişim yaratacak düzeyde planlanması ile birlikte etkililiğinin artırılması için ulusal strateji ve politikalara ihtiyaç duyulmaktadır (Oğuz, Çakcı ve Kavas, 2011). Araştırma kapsamında öğrenciler çevre bilincinin oluşturulmasında devlet ve halkın bir bütün ve eşgüdümlü olarak hareket 
etmesi gerektiğini belirtmişlerdir. Çevre eğitiminin başarılı olması, eğitimin yaygınlaştırılması, temel eğitim süresinin artırılması, çevre derslerinin artırılması ve yaygınlaştırılması gibi siyasal kararlarda devlete önemli görevler düşmektedir (Kılıç ve İnal, 2010).

Çevre bilincinin geliştirilmesine yönelik öneriler kategorisinde yer alan "medyanın kullanımı" teması ile öğrenciler, medya da çevre konusunun çok sınırlı düzeyde yer aldığını belirtmişler ve özellikle medyanın bilinç ve tutum kazandırmada çok yönlü olarak kullanılması gerektiğini önermişlerdir. Çevre temalı TV ve radyo programlarının, öğrencilerin bu tür faaliyetlere katılımını ve motivasyonun artmasında etkili olduğu belirtilmiştir (Anılan, 2014). Medyanın kullanımı, çevreye karşı olumlu tutumların kazandırılmasında ve halkın sürece daha hızlı katılmasında teşvik edici olabilir (Sola, 2014). Ayrıca gelişen teknolojinin yeni firsatlarından yararlanılmasının da toplumda tutum, bilgi ve davranış / kültür değişikliğinde önemli katkılar verebileceği düşünülmektedir. Çevre ile ilgili basılı ve görsel medya yoluyla kitap, dergi gibi kaynaklar öğrencilere ya da topluma daha kolay ulaştırılabilir. Çevre bilincinin işlendiği haberler medyada daha fazla yer bulabilir (Erdoğan ve Uşak, 2009). Bu süreçte devletin denetleme mekanizması kapsamında, topluma doğru ve güvenilir bilginin ulaştırılmasında, önemli rol ve sorumlulukları vardır.

Araştırma sonuçlarına göre, toplumda çevre bilincinin oluşmamasında, hem yönetsel, hem eğitim hem de toplumun farkındalığı ile ilgili sorunlar neden olarak ortaya çıkmıştır. Aynı şekilde çevredeki sorunların çözümünün de yine çok boyutlu olduğu, eğitim temelinde birey ve toplumların sorumlulukları olduğu belirtilmiştir. Özellikle medyanın çevre sorunlarının çözümünde önemli bir araç olduğu vurgulanmıştır. Araştırma verileri araştırmaya katılan kişiler ve araştırma amacıyla oluşturulan görüşme formuyla ile sınırlıdır ve çalışmanın genelleme yapma amacı bulunmamaktadır.

Lisans üstü çevre sağlığı programını devam eden öğrencilerin çevre bilincine yönelik görüşleri doğrultusunda şu önerilerde bulunulabilir:

- Çevre eğitimi bir değişim aracıdır ve toplumun güçlendirilmesine katkı verir. Çevre duyarlılığı ve sevgisinin geliştirilmesi ve sürdürülmesinde sosyal medyanın, çevre eğitiminin bir boyutu olarak hem formal hem de geniş toplumsal kesimleri kapsayan kitlesel eğitimlerde daha aktif olarak kullanılmasına yönelik planlamalar yapılması önerilir.

- Çevre bilincinin oluşmasında kurumlar arası işbirliği yapılması önerilmektedir.

- Çevre bilincinin geliştirilmesi süreci, ilk ve ortaöğretim kademesiyle sinırlı kalmayıp, yükseköğretim kademesinde de devam etmesi önerilmektedir.

- Çevre herkesin ilgi odağında olması gereken bir konu alanıdır. Bu nedenle, çevre duyarlılığının gelişmesinde, olumlu duyguların ve tutumların oluşturulması gerekir. Bu bağlamda, eğiticilerin rol model olma sorumluluğu ile birlikte, eğitimin niteliğini artırıcı aktif öğrenme yöntemleri uygulanmalıdır

\section{Kaynakça}


AMINRAD, Z., ZAKARIYA, S.Z.B.S., HADİ, A.S., SAKARİ, M. (2013). Relationship Between Awareness, Knowledge And Attitudes Towards Environmental Education Among Secondary School Students İn Malaysia. World Applied Sciences Journal, 22 (9), 1326-1333.

ANILAN, B. (2014). A Study Of The Environmental Risk Perceptions And Environmental Awareness Levels Of High School Students. Asia-Pacific Forum on Science Learning and Teaching,15 (2), 1-23.

ASILSOY, B., OKTAY, D. (2018). Exploring Environmental Behaviour As The Major Determinant Of Ecological Citizenship. Sustainable Cities and Society, 39, 765-771.

AYTAÇLI, B. (2012). Durum Çalışmasına Ayrıntılı Bir Bakış. Adnan Menderes Üniversitesi Eğitim Fakültesi Eğitim Bilimleri Dergisi, Haziran 3 (1), 1-9.

BODUR, G., ŞENYUVA, E. (2013). Üniversite Öğrencilerinin Hidroelektrik Enerji Santrallerine (HES) Ilişkin Görüşleri Ile Çevreye Yönelik Tutumları Arasındaki Ilişki. Cumhuriyet International Journal of Education-CIJE, 2 (4), 27-38.

CRESWELL, J. W. (2015). Nitel Araştırma Yöntemleri (2. Baskı) (Çev. Ed. M. Bütün ve S. B. Demir). Ankara: Siyasal Kitabevi.

ÇAKIRLAR, ALTUNTAŞ E., TURAN, S.L. (2016). Çevre Eğitiminde 2010-2015 Y1lları Arasında Yapılan Araştırmalar Ve Eğilimler. Ĕ̈itim ve Toplum Araştırmaları Dergisi/Jres, 3 (2), 1-14

ÇETIN G. NISANCİ, S.H. (2010). Enhancing Students'environmental Awareness. Procedia Social and Behavioral Sciences 2. 1830-1834.

ÇUKUR, D., ÖZGÜNER, H. (2008). Kentsel Alanda Çocuklara Doğa Bilinci Kazandırmada Oyun Mekânı Tasarımının Rolü. Süleyman Demirel Üniversitesi Orman Fakültesi Dergisi , A (2), 177-187.

DOLU, G., ÜREK, H. (2015). Lisansüstü Öğrenciler "Çevre Kirliliği Ve Elektromanyetik Kirlilik” Konusunda Yeterince Bilinçli Mi? NEF-EFMED, 9(1) Haziran,165-183.

ERDOĞAN, M., UŞAK, M. (2009). Currıcular And Extra-Currıcular Actıvitıes To Develop The Environmental Awareness Of Young Students: A Case From Turkey. Odgojne Znanostl, 11(1), 73-85.

HOŞGÖR, H., GÜNDÜZ HOŞGÖR, D., TOSUN, N. (2015). Sağlık Bilimleri Fakültesi Öğrencilerinin Çevreye Yönelik Tutumlarının Belirlenmesi: Kıyaslamalı Bir Analiz. HSP, 2(2),198-207.

KARABIÇAK, M., ARMAĞAN, R. (2004). Çevre Sorunlarının Ortaya Çıkış Süreci, Çevre Yönetiminin Temelleri Ve Ekonomik Etkileri. Süleyman Demirel Üniversitesi İktisadi ve İdari Bilimler Fakültesi, 9(2), 203-228.

KARACA, C. (2007). Çevre, Insan Ve Etik Çerçevesinde Çevre Sorunlarına Ve Çözümlerine Yönelik Yaklaşımlar. Çukurova Üniversitesi İ̈BF Dergisi, 11(1),1-19.

KARATAŞ, A. (2013). The Role Of Faculties Of Education İn Increasing Sustainable Environmental Awareness Of Society. European Journal of Sustainable Development, 2(4), 233-242.

KAYPAK, Ş. (2013). Çevre Sorunlarının Çözümünde Küresel Çevre Politikalarının Önemi. Muğla Sitkı Koçman Üniversitesi Sosyal Bilimler Enstitüsü Dergisi, 31,Güz, 17-34. 
KILIÇ, S., İNAL, M. E. (2010). Yüksek Öğretimde Çevre Eğitimi Alan Ve Almayan Öğrencilerde Çevre Bilinci: Niğde Üniversitesi Örneği. Niğde Üniversitesi İ.I.B.F Dergisi, $3(2), 70-83$.

LITTLEDYKE, M. (2008). Science Education For Environmental Awareness: Approaches To İntegrating Cognitive And Affective Domains, Environmental Education Research,14(1), 1-17, Do1: 10.1080/13504620701843301.

MEIBOUDİ H., KARIMZADEGAN H., KHALILNEJAD S.M.R. (2011). Enhancing Children's Environmental Awareness İn Kindergarten Of Mashhad City Using Mural Painting. Procedia - Social and Behavioral Sciences; 28, 1020 - 1028.

OĞUZ, D., ÇAKCI I., KAVAS, S. (2011). Yüksek Öğretimde Öğrencilerin Çevre Bilinci. SDÜ Orman Fakültesi Dergisi; 12,34-39.

OLSON, J., ZANNA, M. (1994). Attitudes And Attitude Change. Annual Review of Psychology, 44, 117-154.

ÖZDEMİR, O. (2007). Yeni Bir Çevre Eğitimi Perspektifi: "Sürdürülebilir Gelişme Amaçlı Eğitim". Eğitim ve Bilim; 32 (145), 23-38.

PERRON, G.M., COTE R.P., DUFFY, J.F. (2006). Improving Environmental Awareness Training İn Business. Journal of Cleaner Production, 14, 551-562.

SEZEN, J. (2017). Türkiye Ve Dünyada Korunan Alanlara Yönelik Çevre Bilincinin Önemi. Uluslararası Bilimsel Araştırmalar Dergisi IBAD, 2 (2), 165-177.

ŞAŞMAZ, ÖREN F., KIYICI, G., ERDOĞMUŞ, E., SEVINÇ, Ö.S. (2010). Çevre Bilincine Sahip Öğretmen Nitelikleri Ölçeği: Geçerlik Ve Güvenirlik Çalışması. İnönü Üniversitesi Eğitim Fakültesi Dergisi Nisan 11 (1), 133-152.

ŞİMŞEKLİ, Y. (2004). Çevre Bilincinin Geliştirilmesine Yönelik Çevre Eğitimi Etkinliklerine İlköğretim Okullarının Duyarlılığı. Eğitim Fakültesi Dergisi, 17(1), 83-92.

SIMSEKLI, Y. (2015). An Implementation To Raise Environmental Awareness Of Elementary Education Students. Procedia - Social and Behavioral Sciences, 191,222 - 226.

SMIRNOVA, J. (2018). Acquisition Of Environmental Awareness: The Interplay With Institutional Development. International Journal of Economics and Finance, 10(3), 168-180.

SOLA, A.O. (2014). Environmental Education and Public Awareness. Journal of Educational and Social Research May 4 (3), 333-337.

SUBAŞI, M., OKUMUŞ, K. (2017). Bir Araştırma Yöntemi Olarak Durum Çalışması. Atatürk Üniversitesi Sosyal Bilimler Enstitüsü Dergisi, Haziran 21(2), 419-426.

TALAS, M. KARATAŞ, A. (2012). Çevre Bilincinin Geliştirilmesinde Topluma Hizmet Uygulamaları Dersinin Önemi: Niğde Üniversitesi Sınıf Öğretmenliği Programı Örneği. Journal of World of Turks, 4(1):107-123.

TOKAT, N., MUTLU, A. (2004). Çevre Bilinci Ve Duyarlılı̆̆ Bakımından Çorum'daki Orta Öğretim Öğrencileri Üzerine Bir Araştırma. G.Ü.İI.I.B.F.Dergisi, 207-220.

UZUN, N. SAĞLAM, N., VARNACI UZUN, F. (2008). Yeşil Sınıf Modeline Dayalı Uygulamalı Çevre Eğitimi Projesinin Çevre Bilinci Ve Kalıcılığına Etkisi. Ege Eğitim Dergisi, (9) 1, 59-74. 
UZUN, N. SAĞLAM, N. (2007). Orta Öğretimde Çevre Eğitimi Ve Öğretmenlerin Çevre Eğitimi Programları Hakkındaki Görüşleri. Eurasian Journal of Educational Research, 26,176-187.

UZUNBOYLU, H., CAVUS, N. ERCAG, E. (2009). Using Mobile Learning To İncrease Environmental Awareness. Computers \& Education, 52, 381-389.

YAZICI, N., BABALIK, A.A. (2016). Determination Of Environmental Awareness Of University Students: The Case Of Suleyman Demirel University (SDU). Environmental Earth Sciences, 75:190. Do1 10.1007/s12665-015-5032-0

YILDIRIM, A., ŞİMŞEK, H. (2016). Sosyal Bilimlerde Nitel Araştırma Yöntemleri. Genişletilmiş 10. Baskı, Ankara: Seçkin Yayınları.

YURTCANLI DUYMAZ, S. (2013). Çevre Örgütlerinin Çevresel Yönetime Katılma Sürecinde Dayandığı Haklar. TBB Dergisi, (107),173-193. 